\title{
KOMPARASI PENDAPATAN USAHATANI CABAI MERAH DAN PADI SAWAH DI LAHAN IRIGASI PADA MT I DI DESA TRIYOSO BELITANG OKU TIMUR
}

\author{
(Muridin)
}

\begin{abstract}
The purpose of this research is to: (1) Analyze how the history of red chili farming development on irrigated rice field at MT I in Triyoso Village Belitang Sub-District, OKU Timur Regency, (2) Analyze how the income difference between rice farming and red chili farming at MT I In Triyoso Village, Belitang District, OKU Timur Regency. This research was conducted in Triyoso Village, Belitang District, OKU Timur Regency. Site selection was done purposively with the consideration that Triyoso Village is the majority of village inhabitant as farmer and there are some farmers who have cultivated rice paddy and red pepper at MT I. The research will be conducted in June 2015. This research found That the cultivation of red chili has long been dilakanakan in Triyoso Village, but farmers who first cultivate red pepper continuously in irrigated rice fields is Mr. Mardiyanto in 2012. The average total production cost of red chili farming on MT I is $R p$ 12,487.873 / Lg / MT, revenue of $R p$ 24,470,000 / Lg / MT, resulting in revenue of $R p$ 11,982,127 / Lg / MT. The average cost of paddy production production at MT I is $R p 11,568,939 / \mathrm{Lg} / \mathrm{MT}$, the revenue is $R p$ 19,106,204 / Lg / MT, so the income is $R p$ 7.537.265 / Lg / MT. The value of $R / C$ ratio of red chili farmers is 1.96, while the $R / C$ ratio for rice farmers is 1.65 and there is a statistically significant difference between the income of red chili farmers and rice farmers. This can be seen from the value of $t$ arithmetic of 18.36 and table value is 2.10 .
\end{abstract}

Key Words : Agricultural Science, Revenue Comparison, Rice plants, and Chili Farming.

\section{PENDAHULUAN}

\section{A. Latar Belakang}

Pembangunan pertanian tidak hanya diarahkan pada salah satu komoditi pangan tertentu, akan tetapi juga diarahkan pada komoditi-komoditi pangan terutama yang mempunyai nilai ekonomis. Komoditi pangan yang mempunyai nilai ekonomis dan banyak diusahakan masyarakat akhir-akhir ini yaitu hortikultura. Hortikultura meliputi buah-buahan, sayur-sayuran, dan tanaman hias. Pembangunan pertanian dalam hal pengembangan hortikultura tersebut terkait dengan budidaya, hasil olahan dan pemasaran (Sastraatmadja dalam Putri, 2007).

Cabai merupakan produk hortikultura sayuran yang digolongkan ke dalam tiga kelompok yaitu cabai besar, cabai kecil dan cabai hias. Diantara ketiga jenis cabai tersebut, cabai merah merupakan jenis yang paling banyak diperdagangkan dalam masyarakat. Cabai merah terdiri dari cabai merah besar dan cabai merah keriting. Cabai merah besar memiliki kulit permukaan yang lebih halus dibandingkan cabai merah keriting, sedangkan cabai merah keriting memiliki rasa yang lebih pedas dibandingkan cabai merah besar (Sari, 2009).

Cabai merah (Capsicum annuum var. Longum) merupakan salah satu komoditas hortikultura yang memiliki nilai ekonomi penting di Indonesia, karena buahnya selain dijadikan sayuran atau bumbu masak juga mempunyai kapasitas menaikkan pendapatan petani, sebagai bahan baku industri, memiliki peluang ekspor, membuka kesempatan bekerja, serta mengandung vitamin C. Cabai digunakan untuk keperluan rumah tangga dan bahan baku industri obatobatan. Kandungan vitamin $\mathrm{C}$ pada buah cabai cukup tinggi. Hal ini merupakan suatu indikator bahwa cabai dapat dikategorikan sebagai komoditas komersial dan potensial untuk dikembangkan (Santika, 2009).

Cabai merah keriting adalah jenis cabai yang paling digemari di kalangan masyarakat, hal ini dikarenakan hasil pertanian ini sudah menjadi bagian dari budaya makanan kuliner masyarakat Indonesia. Hal ini menunjukkan bahwa cabai merah keriting sangat potensial untuk dibudidayakan oleh petani Indonesia. Saat ini cabai merupakan komoditas penting dalam kehidupan masyarakat di Indonesia. Hampir semua rumah tangga mengkonsumsi cabai setiap hari sebagai pelengkap dalam hidangan keluarga sehari-hari. Konsumsi cabai rata-rata sebesar 4,6 kg per kapita per tahun. Permintaan yang cukup tinggi dan relatif kontinu serta cenderung terus meningkat sehingga akan memberikan dorongan kepada masyarakat luas terutama petani dalam pengembangan budidaya cabai. Umumnya budidaya cabai dilakukan awal musim kemarau dan produksinya akan menurun selama musim penghujan (Anonim, 2008). 
Menurut Dermawan, et all., (2010), salah satu sifat tanaman cabai yang disukai oleh petani adalah tidak mengenal musim. Artinya, tanaman cabai dapat ditanam kapan pun tanpa tergantung musim. Cabai juga mampu tumbuh di rendengan maupun labuhan, itulah sebabnya cabai dapat ditemukan kapan pun di pasar atau di swalayan. Penanaman cabai pada musim hujan mengandung resiko. Penyebabnya adalah tanaman cabai tidak tahan terhadap hujan lebat yang terus menerus. Selain itu, genangan air pada daerah penanaman bisa mengakibatkan kerontokan daun dan terserang penyakit akar. Pukulan air hujan juga bisa menyebabkan bunga dan bakal buah berguguran. Sementara itu, kelembapan udara yang tinggi meningkatkan penyebaran dan perkembangan hama serta penyakit tanaman.

Produksi cabai besar tertinggi di Sumatera Selatan terjadi pada tahun 2012 sebesar 18.058 ton dengan luas panen 5.336 ha yang berarti tingkat produktifitas sebesar 3,38 ton/ha. Produksi cabai besar pada tahun 2013 yaitu sebesar 15.109 ton dengan luas panen mencapai 6.011 ha dengan tingkat produktifitas yaitu sebesar 2,31 ton/ha, mengalami penurunan sebesar 2.949 ton $(16,33$ persen) dibandingkan tahun 2012. Pada tahun 2014 produksi cabai besar sebesar 14.075 ton, mengalami penurunan sebesar 236 ton $(3,94$ persen) dibandingkan tahun 2013.

Tabel 1. Perkembangan Produksi, Luas Panen, dan Produktivitas Cabai Besar di Sumatera Selatan Tahun 2012-2014.

\begin{tabular}{ccccc}
\hline No & Tahun & $\begin{array}{c}\text { Produksi } \\
\text { (ton) }\end{array}$ & $\begin{array}{c}\text { Luas panen } \\
\text { (ha) }\end{array}$ & $\begin{array}{c}\text { Produktifitas } \\
\text { (ton } / \text { ha) }\end{array}$ \\
\hline 1. & 2012 & 18.058 & 5.336 & 3,38 \\
2. & 2013 & 15.109 & 6.011 & 2,51 \\
3. & 2014 & 14.075 & 5.775 & 2,44
\end{tabular}

Sumber: Badan Pusat Statistik Sumsel, 2015.

Kabupaten OKU Timur merupakan salah satu kabupaten yang merupakan lumbung padi di Propinsi Sumatera Selatan dan memiliki potensi besar dalam pengembangan produksi sayuran dan hortikultura terutama budidaya tanaman cabai. Dengan lahan persawahan yang cukup luas dan tersedianya jaringan irigasi teknis maka lahan persawahan tersebut selain digunakan untuk menanam padi maka dapat juga dimanfaatkan untuk budidaya palawija dan berbagai macam tanaman sayuran termasuk cabai merah. Budidaya cabai merah dengan memanfaatkan lahan persawahan ini diharapkan dapat meningkatkan pendapatan petani.
Desa Triyoso merupakan salah satu desa di Kecamatan Belitang yang mayoritas penduduknya memiliki mata pencaharian sebagai petani padi sawah. Di desa ini juga terdapat sebagian petani yang mengusahakan budidaya cabai merah keriting. Petani yang melakukan budidaya cabai merah masih dalam skala kecil dengan memanfaatkan lahan persawahan. Sebagian besar petani pada MT I memanfaatkan lahannya dengan menanam padi. Namun, ada sebagian kecil petani pada MT I yang memanfaatkan lahan sawahnya dengan menanam cabai merah keriting. Budidaya cabai merah memang memerlukan biaya cukup besar, namun apabila diusahakan dengan baik maka keuntungan yang didapat cukup menjanjikan.

\section{B. Rumusan Masalah}

1. Bagaimana sejarah perkembangan usahatani cabai merah pada lahan sawah irigasi pada MT I di Desa Triyoso Kecamatan Belitang OKU Timur.

2. Bagaimana perbedaan pendapatan usahatani cabai merah dengan usahatani padi di lahan sawah irigasi pada MT I di Desa Triyoso Kecamatan Belitang OKU Timur.

\section{Tujuan dan Kegunaan}

1. Menganalisis bagaimana sejarah perkembangan usahatani cabai merah pada lahan sawah irigasi pada MT I di Desa Triyoso Kecamatan Belitang Kabupaten OKU Timur.

2. Menganalisis bagaimana perbedaan pendapatan antara usahatani padi dengan usahatani cabai merah pada MT I di Desa Triyoso Kecamatan Belitang Kabupaten OKU Timur.

\section{Model Pendekatan}

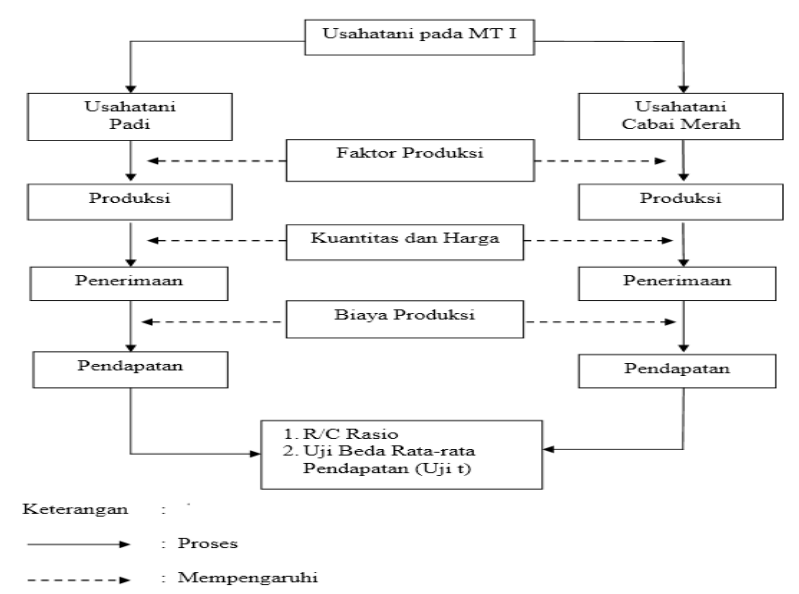

Gambar 1. Model pendekatan penelitian secara diagramatik 


\section{METODOLOGI PENELITIAN}

\section{A. Tempat dan Waktu}

Penelitian ini akan dilaksanakan di Desa Triyoso Kecamatan Belitang Kabupaten OKU Timur. Pemilihan lokasi dilakukan secara sengaja (purposive) dengan pertimbangan bahwa Desa Triyoso merupakan desa yang mayoritas penduduknya bermata pencaharian sebagai petani dan terdapat sebagian petani yang telah mengusahakan budidaya padi sawah dan cabai merah pada MT I. Penelitian akan dilaksanakan pada Bulan Juni 2015.

\section{B. Metode Penelitian}

Metode penelitian yang akan digunakan dalam penelitian ini adalah metode survei yang bertujuan untuk mendapatkan gambaran yang ada di lapangan dengan benar. Menurut Nazir (2003), metode survei adalah penyelidikan yang dilakukan untuk memperoleh fakta-fakta dan gejala-gejala yang ada dan mencari keterangan secara faktual dari suatu kelompok atau suatu daerah tertentu.

\section{Metode Penarikan Contoh}

Pada penelitian ini, responden yang diambil sebagai sampel adalah petani yang mengusahakan budidaya padi dan cabai merah yang berada di Desa Triyoso Kecamatan Belitang. Jumlah petani responden yaitu sebanyak 20 orang yang terdiri dari 5 responden petani cabai merah dan 15 responden petani padi. Pengambilan sampel petani budidaya cabai merah dilakukan dengan metode sensus terhadap semua populasi yang berjumlah 5 responden. Sedangkan pengambilan sampel petani padi sawah dilakukan dengan menggunakan metode sengaja atau tertuju (purposive sampling) terhadap 15 responden dari 160 populasi. Adapun kriteria responden adalah petani padi yang memiliki luas lahan $\geq 1 \mathrm{Bahu}$ $(0,72 \mathrm{Ha})$ pada lahan sawah irigasi dan telah memiliki pengalaman usahatani padi sawah $>10$ tahun.

Tabel 2. Jumlah Sampel dan Populasi Petani Padi

\begin{tabular}{llcc} 
& \multicolumn{2}{c}{ dan Cabai Merah di Desa } & Triyoso, 2015. \\
\hline No & Responden & Sampel & Populasi \\
\hline 1. & Petani Cabai Merah & 5 & 5 \\
2. & Petani Padi & 15 & 160 \\
\hline & Jumlah & 20 & 165
\end{tabular}

Sumber: Data Olahan Primer,2015.

\section{Metode Pengolahan Data}

Untuk menjawab hipotesis penelitian yang pertama yaitu diduga bahwa sejarah perkembangan budidaya cabai merah pada MT I di Desa Triyoso Kecamatan Belitang Kabupaten OKU Timur telah berlangsung lama maka digunakan metode deskriptif atau penjabaran

Untuk menjawab hipotesis penelitian yang kedua yaitu untuk terdapat perbedaan pendapatan usahatani cabai merah dan pendapatan usahatani padi sawah secara signifikan pada MT I di Desa Triyoso Kecamatan Belitang Kabupaten OKU Timur maka dihitung dengan menggunakan rumus sebagai berikut :

1) Untuk mengetahui biaya produksi dengan rumus (Soekartawi, 2002):

$$
\mathrm{TC}=\mathrm{FC}+\mathrm{VC}
$$

Dimana :

$\mathrm{TC}=$ Total Cost/Biaya Total Produksi (Rp/Ha/MT)

$\mathrm{FC}=$ Fixed Cost/Biaya Tetap $(\mathrm{Rp} / \mathrm{Ha} / \mathrm{MT})$

$\mathrm{VC}=$ Variabel Cost/Biaya Variabel $(\mathrm{Rp} / \mathrm{Ha} / \mathrm{MT})$

2) Untuk mengetahui penerimaan digunakan rumus (Soekartawi, 2002):

$$
\mathrm{TR}=\mathrm{Py} \times \mathrm{Y}
$$

Dimana :

$\mathrm{TR}=$ Total Revenue/Total Penerimaan (Rp/Ha/MT)

Py $=$ Price/Harga Jual $(\mathrm{Rp} / \mathrm{Kg})$

$\mathrm{Y}=$ Yield/Hasil Produksi $(\mathrm{Kg} / \mathrm{Ha} / \mathrm{MT})$

3) Untuk menghitung pendapatan, digunakan rumus :

$$
\mathrm{I}=\mathrm{TR}-\mathrm{TC}
$$

Dimana :

$\mathrm{I}=$ Income/Pendapatan $(\mathrm{Rp} / \mathrm{Ha} / \mathrm{MT})$

$\mathrm{TR}=$ Total Revenue/Penerimaan $(\mathrm{Rp} / \mathrm{Ha} / \mathrm{MT})$

$\mathrm{TC}=$ Total Cost/Total Biaya Produksi $(\mathrm{Rp} / \mathrm{Ha} / \mathrm{MT})$

4) $\mathrm{R} / \mathrm{C}$ ratio dihitung dengan menggunakan rumus (Sokartawi, 2002) :

$$
\mathrm{R} / \mathrm{C} \text { Rasio }=\frac{\mathrm{TR}}{\mathrm{TC}}
$$

Dimana :

$\mathrm{TR}=$ Total Revenue $/$ Total Penerimaan

$\mathrm{TC}=$ Total Cost $/$ Total Biaya Produksi

Dengan ketentuan :

R/C Ratio > 1 Berarti usahatani menguntungkan

$\mathrm{R} / \mathrm{C}$ Ratio $=1$ Berarti usahatani tidak untung dan tidak rugi (impas)

$\mathrm{R} / \mathrm{C}$ Ratio < 1 Berarti usahatani tidak menguntungkan (rugi)

5) Selanjutnya untuk menganalisis perbedaan pendapatan usahatani cabai merah dan 
usahatani padi sawah pada MT I di Desa Triyoso Kecamatan Belitang Kabupaten OKU Timur maka dilakukan uji statistik yaitu dengan Uji Beda Dua Sampel Bebas (Independent Samples T-Test).

$$
t=\frac{\overline{X_{1}}-\overline{X_{2}}}{\sqrt{\frac{\left(n_{1}-1\right) S_{1}^{2}+\left(n_{2}-1\right) s_{2}^{2}}{n_{1}+n_{2}-2}\left(\frac{1}{n_{1}}+\frac{1}{n_{2}}\right)}}
$$

dimana :

$\mathrm{t}=$ Nilai $\mathrm{t}$

$\mathrm{n}_{1}=$ Jumlah sampel petani budidaya padi sawah

$\mathrm{n}_{2}=$ Jumlah sampel petani budidaya cabai merah

$\overline{x_{1}}=$ Nilai rata-rata pendapatan usahatani padi sawah

$\overline{x_{2}}=$ Nilai rata-rata pendapatan usahatani cabai merah

$\mathrm{S}_{1}{ }^{2}=$ Varian sampel ke 1

$\mathrm{S}_{2}{ }^{2}=$ Varian sampel ke 2

\section{Dengan kaidah :}

jika t_hit $<\mathrm{t}$ _tabel maka non significant atau tidak terdapat perbedaan yang nyata (signifikan) antara pendapatan usahatani padi dan pendapatan usahatani cabai merah.

jika t_hit > t_tabel maka significant atau terdapat perbedaan yang nyata (signifikan) antara pendapatan usahatani padi dan pendapatan usahatani cabai merah.

\section{HASIL DAN PEMBAHASAN}

\section{A. Analisis Biaya Usahatani Cabai Merah dan Usahatani Padi}

Biaya dalam kegiatan usahatani dikeluarkan oleh petani dengan tujuan untuk menghasilkan pendapatan yang tinggi bagi usahatani yang dikerjakan, dengan mengeluarkan biaya maka pertanian mengharapkan pendapatan yang setinggi-tingginya melalui peningkatan produksi. Biaya dalam kegiatan usahatani terdiri dari biaya tetap (fixed cost) dan biaya variabel (variabel cost).

Biaya tetap (fixed cost) adalah biaya yang relatif tetap jumlahnya dan harus dikeluarkan walaupun produk yang dihasilkan banyak atau sedikit. Biaya tidak tetap (variable cost) adalah biaya yang sifatnya berubah-ubah tergantung dari besar kecilnya produksi yang dihasilkan. Dalam hasil penelitian yang dikelompokkan ke dalam biaya tetap di antaranya adalah biaya sewa lahan dan penyusutan alat. Sedangkan untuk biaya variabel terdiri dari biaya saprodi dan biaya tenaga kerja.

Berikut ini merupakan komponen biaya yang dikeluarkan oleh petani responden usahatani cabai merah dan usahatani padi sawah pada MT I 2016 di Desa Triyoso Kecamatan Belitang :

\section{Biaya Tetap (Fixed Cost)}

Biaya tetap yang digunakan oleh petani responden usahatani cabai merah dan usahatani padi sawah pada MT I 2015 di Desa Triyoso Kecamatan Belitang diantaranya meliputi biaya sewa lahan dan biaya penyusutan peralatan yang dapat dilihat pada tabel berikut :

Tabel 3. Biaya Tetap Usahatani Cabai Merah dan Usahatani Padi di Desa Triyoso pada MT I 2015.

\begin{tabular}{lrrrrr}
\hline \multirow{2}{*}{ No } & Komponen Biaya & \multicolumn{2}{c}{ Usahatani Cabai Merah } & \multicolumn{2}{c}{ Usahatani Padi } \\
\cline { 3 - 6 } & & $(\mathrm{Rp} / \mathrm{Lg} / \mathrm{MT})$ & $(\mathrm{Rp} / \mathrm{Ha} / \mathrm{MT})$ & $(\mathrm{Rp} / \mathrm{Lg} / \mathrm{MT})$ & $(\mathrm{Rp} / \mathrm{Ha} / \mathrm{MT})$ \\
\hline 1. & Sewa Lahan & 1.470 .000 & 5.000 .000 & 3.852 .800 & 4.340 .000 \\
2. Penyusutan Alat & 435.773 & 1.658 .243 & 92.547 & 107.187 \\
\hline & & & & \\
\hline & Biaya Tetap & 1.905 .773 & 6.658 .243 & 3.945 .347 & 4.447 .187
\end{tabular}

Sumber: Data Primer, 2015.

Kegiatan usahatani cabai merah dan usahatani padi di Desa Triyoso Kecamatan Belitang, dalam penggunaan input lahan sebagian besar memiliki status kepemilikan lahan sendiri, namun ada beberapa petani yang memiliki status kepemilikan lahan sewa, sehingga dalam kaidah usahatani semuanya dianggap sebagai lahan sewa. Berdasarkan data di atas bahwa biaya sewa lahan petani usahatani cabai merah dengan luas lahan rata-rata 0,29 Ha memerlukan biaya sebesar $\mathrm{Rp}$ 1.470.000 atau sebesar Rp 5.000.000/Ha. Untuk biaya sewa lahan responden usahatani padi dengan luas lahan rata-rata 0,89 Ha biaya yang dibutuhkan adalah Rp 3.852.800 atau sebesar Rp 4.340.000/Ha.

Biaya penyusutan peralatan yang dihitung meliputi penyusutan peralatan yang terdiri atas cangkul, sumur bor, sabit, parang, ember, handsprayer, mula, rinjing dan roli. Biaya ratarata penyusutan peralatan yang digunakan oleh responden usahatani cabai merah adalah sebesar $\mathrm{Rp}$ 435.773/Lg/MT atau Rp 1.658.243/Ha/MT dan responden usahatani padi adalah sebesar $\mathrm{Rp}$ 92.547/Lg/MT atau Rp 107.187/Ha/MT. Jumlah rata-rata biaya tetap responden usahatani cabai merah adalah sebesar Rp 1.905.773/Lg/MT atau 
sebesar Rp 6.658.243/Ha/MT dan rata-rata biaya tetap responden usahatani padi adalah sebesar Rp 3.945.347/Lg/MT atau sebesar $\mathrm{Rp}$ 4.447.187/Ha/MT.

\section{Biaya Variabel (Variabel Cost)}

Biaya variabel adalah biaya yang digunakan dalam kegiatan usahatani dan biasanya habis dalam satu kali proses produksi. Biaya variabel yang digunakan dalam usahatani cabai merah dan usahatani padi sawah di Desa Triyoso terdiri atas biaya benih, pupuk, pestisida, dan tenaga kerja. Besarnya biaya variabel yang dikeluarkan oleh petani responden usahatani cabai merah dan padi sawah dapat dilihat pada tabel berikut :

Tabel 4. Biaya Variabel Usahatani Cabai Merah dan Usahatani Padi di Desa Triyoso pada MT I 2015.

\begin{tabular}{lcrrrr}
\hline \multirow{2}{*}{ No } & \multirow{2}{*}{ Komponen } & \multicolumn{2}{c}{ Usahatani Cabai Merah } & \multicolumn{2}{c}{ Usahatani Padi } \\
\cline { 3 - 6 } & & $(\mathrm{Rp} / \mathrm{Lg} / \mathrm{MT})$ & $(\mathrm{Rp} / \mathrm{Ha} / \mathrm{MT})$ & $(\mathrm{Rp} / \mathrm{Lg} / \mathrm{MT})$ & $(\mathrm{Rp} / \mathrm{Ha} / \mathrm{MT})$ \\
\hline 1. & Biaya Saprodi & 6.434 .900 & 22.909 .056 & 1.674 .413 & 1.912 .927 \\
2. & Tenaga Kerja & 4.147 .200 & 14.705 .867 & 5.949 .179 & 6.712 .064 \\
\hline & & & & & \\
\hline & Total VC & 10.582 .100 & 37.614 .922 & 7.623 .593 & 8.624 .991
\end{tabular}

Sumber: Data Primer, 2015.

Berdasarkan hasil pada tabel diatas, dapat diketahui bahwa rata-rata penggunaan biaya variabel kegiatan usahatani cabai merah di Desa Triyoso dengan rata-rata lua lahan $0,29 \mathrm{Ha}$ adalah sebesar Rp 10.582.100/Lg/MT atau sebesar Rp $37.614 .922 / \mathrm{Ha} / \mathrm{MT}$. Adapun rata-rata penggunaan biaya variabel kegiatan usahatani padi sawah di Desa Triyoso pada MT I 2015 dengan rata-rata luas lahan garapan $0,89 \mathrm{Ha}$ adalah sebesar Rp 7.623.593/Lg/MT atau sebesar Rp 8.624.991/Ha/MT. Komponen biaya variabel terbesar terdapat pada biaya tenaga kerja.

a. Biaya Saprodi

Penggunaan biaya saprodi dalam kegiatan usahatani cabai merah dan usahatani padi diantaranya digunakan untuk biaya benih, biaya pupuk, biaya insektisida, biaya herbisida dan pembelian karung. Besarnya biaya saprodi yang dikeluarkan oleh responden usahatani cabai merah di Desa Triyoso adalah sebesar 6.434.900 /Lg/MT atau sebesar Rp 22.909.056/Ha/MT. Besarnya biaya saprodi yang dikeluarkan petani responden yang melakukan usahatani padi sawah adalah sebesar Rp 1.674.413/Lg/MT atau sebesar Rp 1.912.927/Ha/MT. Biaya saprodi usahatani cabai merah lebih besar dibandingkan dengan biaya saprodi usahatani padi sawah hal ini disebabkan karena tanaman cabai merah banyak sekali ancaman hama dan penyakit yang menyerang sehingga diperlukan perawatan dan pengendalian OPT yang intensif.

b. Biaya Tenaga Kerja

Tenaga kerja merupakan salah satu faktor produksi yang memiliki pengaruh besar terhadap biaya usahatani. Oleh karena itu dalam penggunaannya petani harus memperhitungkannya. Kebutuhan tenaga kerja dalam satu musim tanam yang digunakan petani baik yang melakukan usahatani cabai merah maupun usahatani padi di Desa Triyoso pada umumnya relatif sama yaitu terdiri dari biaya pengolahan lahan, biaya semai, tanam, penyulaman, penyiangan, pemupukan dan pengendalian OPT dan biaya pemanenan. Dalam usahatani padi biasanya ditambah lagi dengan biaya konsumi dan transportasi panen.

Adapun besarnya rata-rata biaya tenaga kerja dalam kegiatan usahatani cabai merah di Desa Triyoso dalam satu kali musim tanam dengan rata-rata luas lahan $0,29 \mathrm{Ha}$ adalah sebesar Rp. 4.147.200 atau sebesar Rp 14.705.867/Ha/MT. Sedangkan total biaya tenaga kerja yang dikeluarkan oleh petani yang melakukan usahatani padi dengan luas garapan rata-rata $0,89 \mathrm{Ha}$ adalah sebesar $\mathrm{Rp}$ 5.949.179/Lg/MT atau sebesar Rp 6.712.064/Ha/MT.

\section{Biaya Total (Total Cost)}

Biaya total produksi dalam kegiatan usahatani terdiri dari biaya tetap ditambah dengan biaya variabel. Besarnya biaya total yang dikeluarkan oleh petani responden usahatani cabai merah dan usahatani padi sawah di Desa Triyoso pada MT I 2015 dapat dilihat pada tabel berikut :

Tabel 5. Biaya Total Usahatani Cabai Merah dan Usahatani Padi di Desa Triyoso pada MT I 2015.

\begin{tabular}{lrrrrr}
\hline \multirow{2}{*}{ No } & \multirow{2}{*}{ Komponen } & \multicolumn{2}{c}{ Usahatani Cabai Merah } & \multicolumn{2}{c}{ Usahatani Padi } \\
\cline { 3 - 6 } & & $(\mathrm{Rp} / \mathrm{Lg} / \mathrm{MT})$ & $(\mathrm{Rp} / \mathrm{Ha} / \mathrm{MT})$ & $(\mathrm{Rp} / \mathrm{Lg} / \mathrm{MT})$ & $(\mathrm{Rp} / \mathrm{Ha} / \mathrm{MT})$ \\
\hline 1. & Biaya Tetap & 1.905 .773 & 6.658 .243 & 3.933 .793 & 4.433 .836 \\
2. & Biaya Variabel & 10.582 .100 & 37.614 .922 & 7.623 .593 & 8.624 .991 \\
\hline & & & & & \\
\hline & Biaya Total & 12.487 .873 & 44.273 .165 & 11.557 .386 & 13.058 .827
\end{tabular}

Sumber: Data Primer, 2015.

Berdasarkan hasil pada tabel diatas, dapat diketahui bahwa biaya total produksi yang dikeluarkan reponden usahatani cabai merah pada MT I 2015 di Desa Triyoso dalam satu musim tanam dengan rata-rata luas garapan 0,29 $\mathrm{Ha}$ adalah sebesar Rp 12.487.873 atau sebesar $\mathrm{Rp}$ 44.273.165/Ha/MT. Adapun biaya total produksi petani responden usahatani padi pada MT I dalam satu musim tanam dengan rata-rata luas garapan 
0,89 Ha adalah sebesar Rp 11.557.386 atau sebesar Rp 13.058.827/Ha/MT. Total biaya produksi petani responden usahatani cabai merah dalam satu musim tanam lebih besar dibandingkan total biaya produksi petani responden usahatani padi sawah.

\section{B. Produksi, Harga Jual, Penerimaan dan Pendapatan}

Hasil akhir atau yang lebih dikenal dengan produksi secara teknis adalah sesuatu proses pendayagunaan sumber-sumber yang tersedia dengan harapan terwujudnya hasil yang lebih dari segala pengorbanan yang diberikan. Produksi yang dihasilkan oleh petani yang melakukan usahatani cabai merah adalah berupa cabai merah keriting. Sedangkan produksi yang dihasilkan oleh petani yang melakukan usahatani padi awah adalah berupa Gabah Kering Panen (GKP).

Penerimaan merupakan hasil kali antara produksi yang dihasilkan dalam satu satuan fisik dengan harga jual produk tersebut. Biasanya penerimaan dari setiap petani tidak sama walaupun luas garapan dan komoditi yang diusahakan sama. Pendapatan usaha tani merupakan selisih antara penerimaan dengan semua biaya produksi. Dengan kata lain pendapatan merupakan penerimaan bersih usaha. Berikut adalah produksi, harga jual, penerimaan, dan pendapatan responden usahatani cabai merah dan usahatani padi pada MT I 2015 di Desa Triyoso.

Tabel 6.Produksi Penerimaan dan Pendapatan Responden Usahatani Cabai Merah di Desa Triyoso pada MT I 2015.

\begin{tabular}{rlrr}
\hline No & Uraian & \multicolumn{3}{c}{ Nilai } \\
\hline 1. & Produksi $/ \mathrm{Lg} / \mathrm{MT})$ & \multicolumn{2}{c}{$(\mathrm{Rp} / \mathrm{Ha} / \mathrm{MT})$} \\
2. & Harga Jual & 955 & 3.337 \\
3. & Penerimaan & 25.625 & 25.625 \\
4. & Biaya Produksi & 24.470 .000 & 85.499 .518 \\
5. & Pendapatan & 12.487 .873 & 44.273 .165 \\
6. & R/C rasio & 11.982 .127 & 41.226 .353 \\
& & 1,96 & 1,96 \\
& & &
\end{tabular}

\section{Sumber: Data Primer, 2015.}

Rata-rata produksi cabai merah yang dihasilkan oleh petani dalam usahatani cabai merah di Desa Triyoso pada MT I 2015 dengan luas garapan rata-rata $0,29 \mathrm{Ha}$ adalah sebesar 955 $\mathrm{Kg} / \mathrm{MT}$ atau sebesar $3.337 \mathrm{Kg} / \mathrm{Ha} / \mathrm{MT}$. Rata-rata harga jual cabai merah adalah sebesar $\mathrm{Rp}$ $25.625 / \mathrm{Kg}$ sehingga menghasilkan rata-rata penerimaan sebesar Rp 24.470.000/Lg/MT atau rata-rata penerimaan sebesar
85.499.518/Ha/MT. Total biaya produksi usahatani cabai merah adalah sebesar Rp 12.487.873/Lg/MT atau sebesar Rp 44.273.165/Ha/MT sehingga menghasilkan ratarata pendapatan sebesar $\mathrm{Rp} 11.982 .127 / \mathrm{Lg} / \mathrm{MT}$ atau pendapatan sebesar Rp 41.226.353/Ha/MT. Nilai R/C rasio usahatani cabai merah adalah sebesar 1,96 yang artinya dalam setiap Rp 1 biaya yang digunakan untuk usahatani cabai merah maka akan menghasilkan penerimaan sebesar $\mathrm{Rp}$ 1,96 .

Adapun produksi, harga jual, biaya produksi, penerimaan, pendapatan usahatani padi sawah di Desa Triyoso pada MT I 2015 ditunjukkan pada tabel berikut :

Tabel 7. Produksi, Penerimaan dan Pendapatan Usahatani Padi di Desa Triyoso pada MT I 2015.

\begin{tabular}{llrr}
\hline No & Uraian & $(\mathrm{Rp} / \mathrm{Lg} / \mathrm{MT})$ & \multicolumn{2}{c}{ Nilai } & \\
& & 5.469 & 6.171 \\
1. & Produksi GKP & 3.495 & 3.495 \\
2. & Harga Jual GKP & 19.106 .204 & 21.556 .972 \\
3. & Penerimaan & 11.568 .939 & 13.072 .178 \\
4. & Biaya Produksi & 7.537 .265 & 8.484 .794 \\
5. & Pendapatan & 1,65 & 1,65 \\
6. & R/C rasio & &
\end{tabular}

Sumber: Data Primer, 2015.

Rata-rata produksi gabah kering penen (GKP) yang dihasilkan oleh petani dalam usahatani padi sawah pada MT I 2015 di Desa Triyoso dengan luas lahan rata-rata $0,89 \mathrm{Ha}$ adalah $5.469 \mathrm{Kg} / \mathrm{Lg} / \mathrm{MT}$ atau $6.171 \mathrm{Kg} / \mathrm{Ha} / \mathrm{MT}$, dengan rata-rata harga jual GKP sebesar Rp $3.493 / \mathrm{Kg}$ sehingga menghasilkan rata-rata penerimaan sebesar $19.106 .204 / \mathrm{Lg} / \mathrm{MT}$ atau sebesar Rp 21.556.972/Ha/MT. Total biaya produksi usahatani padi adalah sebesar Rp 11.568.939/Lg/MT atau sebesar Rp 13.072.178 sehingga rata-rata pendapatan yang diperoleh adalah sebesar Rp 7.537.265/Lg/MT atau sebesar Rp 8.484.794/Ha/MT. Nilai R/C ratio adalah sebesar 1,65 artinya setiap satu rupiah biaya yang dikeluarkan untuk usahatani padi akan menghasilkan penerimaan sebesar $\mathrm{Rp}$ 1,65. Berdasarkan analisis di atas dapat diimpulkan bahwa penerimaan, pendapatan dan nilai $\mathrm{R} / \mathrm{C}$ rasio usahatani cabai merah lebih besar dibandingkan dengan usahatani padi. Hal ini menunjukkan bahwa usahatani cabai merah lebih menguntungkan dibandingkan dengan usahatani padi pada MT I 2015 di Desa Triyoso. 


\section{Uji Beda Pendapatan Usahatani Cabai Merah dan Usahatani Padi}

Untuk mengetahui apakah terdapat perbedaan yang signifikan antara pendapatan usahatani cabai merah dan usahatani padi di Desa Triyoso pada MT I 2015 maka digunakan analisa uji beda rata-rata (uji t-test) dengan bantuan program Microsoft Exel. Uji-t adalah uji komparatif atau uji beda untuk mengetahui adakah perbedaan mean atau rerata yang bermakna antara 2 kelompok bebas yang berskala data interval/rasio. Dua kelompok bebas yang dimaksud di sini adalah antara pendapatan usahatani cabai merah dan usahatani padi.

Tabel 8. Perbandingan Rata-rata Pendapatan Usahatani Cabai Merah dan Usahatani Padi di Desa Triyoso pada MT I 2015.

\begin{tabular}{lcrr}
\hline No & Komponen & Usahatani Cabai Merah & Usahatani Padi \\
\hline 1. & Penerimaan $(\mathrm{Rp} / \mathrm{Ha} / \mathrm{MT})$ & 85.499 .518 & 21.556 .972 \\
2. & Biaya Total $(\mathrm{Rp} / \mathrm{Ha} / \mathrm{MT})$ & 44.273 .165 & $13.072 . .178$ \\
3. & Pendapatan $(\mathrm{Rp} / \mathrm{Ha} / \mathrm{MT})$ & 41.266 .353 & 8.484 .794 \\
4. & R/C Rasio & 1,96 & 1,65 \\
\hline
\end{tabular}

Sumber: Data Primer, 2015.

Berdasarkan tabel di atas menunjukkan bahwa rata-rata pendapatan usahatani cabai merah adalah sebesar $\mathrm{Rp}$ 41.266.353/Ha/MT dan besarnya rata-rata pendapatan yang diperoleh dari responden usahatani padi adalah sebesar Rp 8.484.794/Ha/MT. Rata-rata pendapatan responden usahatani cabai merah lebih tinggi daripada pendapatan responden usahatani padi dengan selisih pendapatan sebesar Rp 32.749.882/Ha/MT. Hal ini menunjukkan bahwa usahatani cabai merah pada MT I lebih menguntungkan dibandingkan dengan usahatani padi di Desa Triyoso Kecamatan Belitang OKU Timur. Berikut Hasil Independent Sampel Test :

$$
\begin{aligned}
& \text { 1. } \quad \frac{\left(n_{1}-1\right) S_{1}^{2}+\left(n_{2}-1\right) S_{2}^{2}}{n_{1}+n_{2}} \\
& =11.923 \cdot 433 \cdot 212 \cdot 326,30 \\
& \text { 2. }\left(\frac{1}{n_{1}}+\frac{1}{n_{2}}\right) \\
& \text { 3. } \quad \frac{\left(n_{1}-1\right) S_{1}^{2}+\left(n_{2}-1\right) S_{2}^{2}}{n_{1}+n_{2}}\left(\frac{1}{n_{1}}+\frac{1}{n_{2}}\right) \\
& \text { 4. } \sqrt{\frac{\left(n_{1}-1\right) S_{1}^{2}+\left(n_{2}-1\right) S_{2}^{2}}{n_{1}+n_{2}}\left(\frac{1}{n_{1}}+\frac{1}{n_{2}}\right)} \quad=\quad 1.783 .138,298 \\
& \text { 5. } \mathrm{t} \text {-hit }=\frac{\overline{\mathrm{x}} 1-\overline{\mathrm{x}} 2}{\sqrt{\frac{\left(n_{1}-1\right) S_{1}^{2}+\left(n_{2}-1\right) S_{2}^{2}}{n_{1}+n_{2}}\left(\frac{1}{n_{1}}+\frac{1}{n_{2}}\right)}} \quad=\quad 18,36 \\
& \text { 6. t-tabel } \\
& 2,10
\end{aligned}
$$

Sumber : Data Primer, 2015.
Berdasarkan hasil analisis uji- $\mathrm{t}$ diperoleh hasil : pada tingkat kepercayaan $95 \%$ dan tingkat error 5\% $(\alpha=0,05)$ diperoleh nilai t-hit $=18,36$ dan nilai t-tabel $=2,10$. Dengan demikian nilai $t-$ hit > t-tabel, yang artinya bahwa terdapat perbedaan yang signifikan (nyata) antara pendapatan usahatani cabai merah dengan pendapatan usahatani padi pada MT 12015 di Desa Triyoso Kecamatan Belitang Kabupaten OKU Timur.

\section{IV.KESIMPULAN DAN SARAN}

\section{A. Kesimpulan}

Berdasarnya hasil penelitian dan analisis yang telah dilakukan, maka dapat ditarik kesimpulan sebagai berikut:

1. Budidaya cabai merah sudah sejak lama dilakanakan di Desa Triyoso namun petani yang pertama kali mengusahakan budidaya cabai merah secara kontinyu di lahan sawah irigasi adalah Bapak Mardiyanto yaitu pada tahun 2012.

2. Rata-rata total biaya produksi usahatani cabai merah pada MT I adalah sebesar Rp 12.487.873/Lg/MT, penerimaan sebesar $\mathrm{Rp}$ 24.470.000/Lg/MT, sehingga diperoleh pendapatan sebesar Rp 11.982.127/Lg/MT. Adapun rata-rata biaya produksi usahatani padi pada MT I adalah sebesar Rp 11.568.939/Lg/MT, penerimaan sebesar Rp 19.106.204/Lg/MT, sehingga diperoleh pendapatan sebesar $\mathrm{Rp}$ 7.537.265/Lg/MT. Nilai R/C ratio responden usahatani cabai merah adalah sebesar 1,96 sedangkan nilai $\mathrm{R} / \mathrm{C}$ rasio untuk responden usahatani padi adalah sebesar 1,65.

3. Secara statistik terdapat perbedaan yang nyata (signifikan) antara pendapatan responden usahatani cabai merah dan responden usahatani padi. Hal ini dapat dilihat dari nilai $t$ hitung sebesar 18,36 dan nilai t tabel adalah 2,10 .

\section{B. Saran}

1. Berdasarkan penelitian yang dilakukan pelaksanaan usahatani cabai merah pada MT I lebih menguntungkan dibandingkan dengan usahatani padi, untuk itu sebaiknya petani dapat mencoba untuk melakukan usahatani cabai merah.

2. Terdapat beberapa kendala yang dihadapi petani padi sawah untuk beralih melakukan 
budidaya cabai merah diantaranya adalah : biaya produksi untuk budidaya cabai merah yang besar, banyaknya hama dan penyakit yang menyerang tanaman cabai merah sehingga diperlukan perawatan yang intensif serta harga cabai yang fluktuatif yang terkadang sangat merugikan petani.

3. Perlu dilakukan penelitian lanjutan mengenai kendala dan faktor-faktor apa saja yang membuat petani tidak melakukan budidaya cabai merah pada MT I.

\section{DAFTAR PUSTAKA}

Anonim. 2009. Tanaman Padi. Departemen Pertanian. Jawa Barat.

Anonim. 2010. Laporan Tahunan Tanaman. Dinas Pertanian Tanaman Pangan dan Hortikultura Kabupaten OKU Timur.

Anonim. 2011. Pertumbuhan Penduduk Indonesia. BPS Jakarta.

Azzoino. 2003. Ilmu Usahatani. Universitas Terbuka. Jakarta.

Daniel, Mosher. 2002. Metode Penelitian Sosial Ekonomi di Lengkapi Beberapa Alat Dan Analisa dan Penuntut Pengguna. Jurnal Ilmi-ilmu Pertanian. Vol. 5, No 1, pp. 1-21.

Endah. 2003. Penggunaan Pestisida. PT Agro Media. Jakarta.

Glaszman. 1987. Botani Padi. Pustaka Sinar Harapan. Jakarta.

Hernanto, F. 2005. Ilmu Usaha Tani I. Penebar Swadaya. Jakarta.

Ibrahim. 2003. Study Kelayakan Bisnis. PT Rineka Cipta. Jakarta.

Joesi. 2008. Penanganan Pasca Panen. Sinar Tani. Yogyakarta.

Kartasoepatra, A.G. 2006. Pengantar Ekonomi Produksi. Bina Aksana. Jakarta.

Koutsoyiannis, A. $2004 . \quad$ Modern Microeconomics, Second Edition, Macmillan Education LTD Houndmills, Basingstoke, Hamspire RG21 2XS. London.
Mubyarto. 2007. Pengantar Ekonomi Pertanian. LP3ES. Jakarta.

Novizan. 2003. Petunjuk Pemakaian Air. PT Agro Media. Jakarta.

Nurhayati. 2001. Ekonomi Pertanian. Universitas Terbuka. Jakarta.

Purnawati. 2007. Analisis Usaha Tani. Fakultas Pertanian Universitas Gajah Mada. Yogyakarta.

Saragih, B. 2001. Kumpulan Pemikiran Agribisnis Paradigma Baru Pembangunan Ekonomi Berbasis Pertanian. Pustaka Wirausaha Muda. Bogor.

Setiadi. 2007. Bertanam sayuran. Penebar swadaya. Jakarta.

Setyono. 2006. Padi Sawah Varietas Unggul. Rineka Cipta. Jakarta.

Shim, Jae K, Ph. D. And Joel G. Siegel, Ph. D., CPA. 1992. Modern Cost Management \& Analysis, Barron's Educational Series, Inc. 250 Wireless Boulvard Hauppaunge, New York 11788.

Shinji. 2012. Usahatani. http://Shinjiblack.blogspot.co.id/2012/06/usahatani.htm 1. Diakses pada tanggal 06 Mei 2015.

Sjarkowi, F. 2010. Manajemen Agribisnis. CV Baldad Grafiti Press. Palembang.

Sjarkowi, F danSufri, M. 2004. Manajemen Agribisnis. CV Baldad Grafiti Press. Palembang.

Soekartawi. 2004. Prinsip Dasar Ekonomi Pertanian. Raja Grafindo Persada. Jakarta.

Soekartawi. 2005. Teori Ekonomi Produksi. CV Rajawali. Jakarta.

Sudarsono. 2004. Pengantar Ekonomi Micro. LP3ES. Jakarta.

Sugiyono. 2012. Metode Penelitian Bisnis. Alfabeta. Bandung.

Sunarjono, H. 2005. Bertanam 30 Jenis Sayur. Jakarta; PT Penebar Swadaya. 
Suratiyah, Ken. 2006.Ilmu Usahatani. Cetakan I. Penerbit Penebar Swadaya. Jakarta.

Tambunan, T. 2010. Pembangunan Pertanian dan Ketahanan Pangan. Universitas Indonesia-press. Jakarta.

Toher, K. 2006. Seuntai Pengetahuan Tentang Usahatani Indonesia. PT Bina Aksara. Jakarta.

Umar, H. 2002. Riset Pemasaran dan Perilaku Konsumen. PT. Gramedia Pustaka Utama. Jakarta.

Wisynu.2014. Usahatani. Wisynu.lecture.ub.ac.id. diakses pada tanggal 06 Mei 2015.
Zaifbio. 2014. Pola Tanam. https://zaifbio.wordpress.com/tag/polatanam/. Diakses pada tanggal 06 Mei 2015. 